\title{
Detecção de Ornithobacterium rhinotracheale (ORT) por meio da reação em cadeia da polimerase (PCR)
}

\author{
Polymerase chain reaction (PCR) detection of Ornthobacterium \\ rhinotracheale (ORT) \\ Cláudio Wageck Canal ${ }^{1}$ Silvio Luís da Silveira Rocha ${ }^{2}$ Joice \\ Aparecida Leão ${ }^{3}$ Luiz Cezar Bello Fallavena ${ }^{4}$ Silvia Dias de \\ Oliveira $^{5}$ Nilzane Beltrão ${ }^{5}$
}

\begin{abstract}
- NOTA -
RESUMO

Ornithobacterium rhinotracheale (ORT) é uma bactéria Gram negativa recentemente descrita que se encontra associada às doenças do trato respiratório em criações de aves comerciais e silvestres em vários países do mundo. No Brasil, foram detectados anticorpos em um pequeno número de frangos de corte e suas matrizes dos Estados de São Paulo e Minas Gerais. Como a bactéria é fastidiosa, a Reação em Cadeia da Polimerase (PCR) torna-se útil para sua detecção e identificação. O presente trabalho visou verificar a ocorrência da ORT no Rio Grande do Sul pela detecção do DNA da bactéria. Foram coletadas 84 amostras de suabe de traquéia de aves pertencentes a 14 lotes de diferentes empresas avicolas. $O$ DNA foi purificado e a PCR realizada com iniciadores específicos para o gene do RNA ribossomal $16 S$ da ORT. Foram observados produtos de amplificação com 784 pares de bases em 10 das 84 amostras. As amostras positivas pertenciam a quatro lotes de três empresas estabelecidas em diferentes regiões do RS. Os resultados indicam que este patógeno respiratório de aves existe no Brasil e está presente em importantes regiões criatórias do RS. Outros estudos estão em andamento para determinar a prevalência e caracterização dos isolados obtidos.

ABSTRACT

Ornithobacterium rhinotracheale (ORT) is a recently discovered Gram negative bacterium that has been associated with respiratory diseases in commercial poultry and wild birds from many countries. In Brazil, antibodies were detected in some broiler and breeder flocks from the States of São Paulo and Minas Gerais. Because the bacteria is difficult to grow, the Polymerase Chain Reaction (PCR) has been found to be suitable for identification and diagnostic purposes. The aim of the present work was to verify the occurrence of ORT in Rio Grande do Sul through the detection of the bacteria DNA. Tracheal swabs (84) were collected from 14 broiler flocks of distinct companies. DNA was purified and PCR performed with species specific primers from the ORT $16 S$ ribosomal $R N A$ gene. Amplification products with 784 base pairs were obtained from 10 out of the 84 samples. The positive samples were from four flocks of tree companies established in different regions of the state. The results indicate that this respiratory pathogen occurs in major broiler producing areas from the State of Rio Grande do Sul. Further studies are under way to determine the prevalence of this pathogen and to characterize the strains isolated.
\end{abstract}

Palavras-chave: Ornithobacterium rhinotracheale, patologia aviária, PCR, detecção, identificação.
Key words: Ornithobacterium rhinotracheale, avian pathology, PCR, detection, identification.

\footnotetext{
'Médico Veterinário, Doutor, Professor Adjunto, Centro de Diagnóstico e Pesquisa em Patologia Aviária (CDPA), Departamento de Medicina Animal, Faculdade de Veterinária da Universidade Federal do Rio Grande do Sul (UFRGS) - Av. Bento Gonçalves 8824, 91540-000,Porto Alegre, RS. E-mail: canal@dna.cbiot.ufrgs.br. Autor para correspondência.

${ }^{2}$ Biólogo, Mestrando, (CDPA), Departamento de Medicina Animal, Faculdade de Veterinária da UFRGS.

${ }^{3}$ Médico Veterinário, Mestre, (CDPA), Departamento de Medicina Animal, Faculdade de Veterinária da UFRGS.

${ }^{4}$ Médico Veterinário, Doutor, (CDPA), Departamento de Medicina Animal, Faculdade de Veterinária da UFRGS - Professor Adjunto, Universidade Luterana do Brasil (ULBRA).

${ }^{5}$ Médico Veterinário, Mestre, Doutoranda, (CDPA), Departamento de Medicina Animal, Faculdade de Veterinária da UFRGS.
} 
As doenças respiratórias que afetam as aves domésticas criadas comercialmente geram perdas econômicas pelo aumento da mortalidade, custos com medicamentos, queda de postura, redução da qualidade e da eclodibilidade dos ovos, entre outras. Vários vírus e bactérias podem ser responsáveis por estas doenças do trato respiratório, sozinhos ou associados a outros microrganismos, além de sofrerem a influência de fatores não infecciosos, como condições climáticas ou manejo impróprio.

Ornithobacterium rhinotracheale (ORT) é uma bactéria recentemente descrita (VANDAMME et al., 1994) que foi associada com doenças do trato respiratório em criações de aves comerciais e silvestres. Sua origem é desconhecida, sendo a hipótese mais provável, que tenha se adaptado de aves silvestres para as domésticas (AMONSIN et al., 1997).

A ORT é um bastonete Gram negativo, imóvel, pleomórfico, não esporulado, pertencente a rRNA superfamília V. Não apresenta estruturas ou propriedades especiais, como, pili, fímbrias e plasmídios ou atividades tóxicas específicas (LEROY-SÉTRIN et al., 1998). Taxonomicamente, se assemelha aos gêneros Cytophaga, Riemerella, Flavobacterium, Weeksella, Sporocytophaga e Capnocytophaga. A ORT possui considerável variação antigênica, com onze sorotipos identificados e designados por letras de A até L, sendo o sorotipo A o mais prevalente tanto em perus quanto em galinhas (BACK et al., 1998). A caracterização genética da bactéria tem demonstrado que provavelmente existam mais espécies ou subespécies dentro do gênero Ornithobacterium (VAN EMPEL \& HAFEZ, 1999).

A infecção pela ORT é caracterizada por pneumonia uni ou bilateral, pleurite, aerossaculite e pode ser agravada por outros fatores, tais como viroses respiratórias, bactérias ou condições climáticas. A bactéria pode ser transmitida verticalmente e horizontalmente por aerossol, o que explica sua rápida difusão por todo o mundo. $\mathrm{O}$ tratamento da enfermidade pode ser difícil, devido à resistência adquirida aos antimicrobianos convencionais. A vacinação através de bacterinas autógenas apresenta bons resultados, mas seu sucesso depende do adjuvante utilizado (VAN EMPEL \& BOSCH, 1998).

A detecção de anticorpos específicos pode ser feita através de ensaios imunoenzimáticos (VAN EMPEL et al., 1997) e soroaglutinação rápida em placa (BACK et al.,1998), já a detecção da bactéria pode ser feita pelo isolamento e caracterização bioquímica e sorológica. Como a bactéria cresce lentamente, compete mal com outras espécies presentes na amostra e é de difícil caracterização bioquímica, a Reação em
Cadeia da Polimerase (PCR) torna-se útil para sua detecção e identificação (VAN EMPEL \& HAFEZ, 1999). A ORT já foi isolada de aves na África, Ásia e Europa (VAN EMPEL \& HAFEZ, 1999). No Brasil, foram detectados anticorpos por ELISA indireto em $50,8 \%$ de 63 amostras de soros de aves dos Estados de SP e MG (ARNS et al., 1998). O presente trabalho visou verificar a ocorrência da ORT no Rio Grande do Sul através da detecção do DNA da bactéria.

Foram coletados suabes de traquéia de seis frangos de corte de cada um dos 14 lotes de diferentes empresas avícolas, totalizando 84 amostras. A haste dos suabes foi cortada e as pontas acondicionadas em tubos de 1,5 mL com tampão $10 \mathrm{mM}$ Tris-. $\mathrm{HCl}$ pH 8,0 e 1 mM EDTA (TE). O DNA foi preparado pela digestão com proteinase K e SDS seguida de extração com fenolclorofórmio (SAMBROOK et al., 1989). Após a precipitação com acetato de sódio e isopropanol, o DNA foi resuspendido em $50 \mu \mathrm{L}$ de TE. A PCR foi realizada em um volume final de $25 \mu \mathrm{L}$, contendo $2 \mu \mathrm{L}$ (aproximadamente $100 \mathrm{ng}$ ) de DNA, 0,2 mM de cada nucleotídeo (GibcoBRL), $1 \mathrm{U}$ de Taq DNA polimerase (Cenbiot Enzimas), 2,5 $\mathrm{mM} \mathrm{MgCl}_{2}, 10 \mathrm{mM}$ Tris $\mathrm{HCl}, 5$ $\mathrm{mM} \mathrm{KCl}$ e $0,8 \rho \mathrm{mol} / \mu \mathrm{L}$ de cada um dos iniciadores específicos para o gene do RNA ribossomal $16 \mathrm{~S}$ do ORT (VAN EMPEL \& HAFEZ, 1999). A amplificação foi realizada em um termociclador Perkin Elmer modelo GeneAmp PCR System 2400 com um ciclo de $94^{\circ} \mathrm{C}$ por 5 minutos, seguidos de 35 ciclos de desnaturação a $94^{\circ} \mathrm{C}$ por 30 segundos, anelamento a $58^{\circ} \mathrm{C}$ por 60 segundos e extensão a $72^{\circ} \mathrm{C}$ por 90 segundos, seguido de uma extensão final a $72^{\circ} \mathrm{C}$ por 7 minutos. Em todas as reações foi utilizado um isolado de ORT como controle positivo e isolados de Pasteurella multocida e Reimerella anatispestifer como controles negativos. Os produtos de amplificação foram submetidos à eletroforese em gel de agarose a $1 \%$ corado com brometo de etídeo e visualizados sob luz ultravioleta.

Foram observados produtos de amplificação com 784 pares de bases do controle positivo e de 10 das 84 amostras de suabe de traquéia (Figura 1). As amostras positivas pertenciam a quatro lotes de três empresas estabelecidas em diferentes regiões do Rio Grande do Sul.

Os resultados reforçaram o relato de ARNS et al. (1998) que detectaram a presença de anticorpos para ORT em aves de alguns lotes do Estado de São Paulo e Minas Gerais, reforçando a idéia de que este patógeno respiratório de aves existe no Brasil e está presente em importantes regiões criatórias do Rio Grande do Sul.

A rapidez na obtenção do resultado da identificação da ORT pela detecção de seu DNA em 


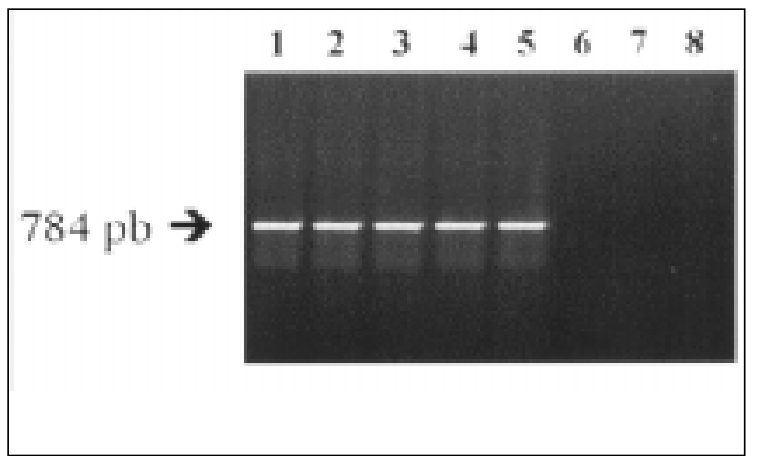

Figura 1 - Fotografia de gel de agarose $1 \%$ corado com brometo de etídio da eletroforese dos produtos de amplificação com $784 \mathrm{pb}$ de Ornithobacterium rhinotracheale. Produtos de amplificação obtidos a partir do DNA extraído de cultura de ORT (linha 1) utilizada como controle positivo; produtos de amplificação obtidos a partir do DNA extraído de traquéias de frangos de corte do lote 11 (linha 2), lote 27 (linha 3), lote 29 (linha 4) e lote 34 (linha 5) que resultaram positivos, lote 5 (linha 6) e lote 30 (linha 7) que resultaram negativos, cultura de Pasteurella multocida (linha 8) utilizada como controle negativo.

comparação ao método bacteriológico convencional, tornam a PCR um instrumento alternativo e prático à disposição do laboratório de diagnóstico, pois elimina o tempo de incubação, isolamento e testes bioquímicos.

Um estudo mais amplo está sendo executado para isolar esta bactéria por exame microbiológico convencional e caracterizá-la bioquímica e morfologicamente. Um estudo epidemiológico também está sendo conduzido para determinar a prevalência das infecções por ORT em matrizes e em frangos de corte com e sem doença respiratória, de modo a correlacionar a sua presença com a doença. Os dados gerados permitirão avaliar a importância da Ornithobacterium rhinotracheale na sanidade avícola e embasar programas de controle para enfermidades respiratórias.

\section{REFERÊNCIAS BIBLIOGRÁFICAS}

AMONSIN, A. et al. Molecular epidemiology of Ornithobacterium rhinotracheale. Journal of Clinical Microbiology, v.35, n.11, p.2894-2898, 1997.

ARNS, C.W. et al. Ornithobacterium rhinotracheale: Detecção sorológica em aves matrizes e frangos de corte. In: CONFERÊNCIA ApInco, 1998, Campinas SP. Trabalhos concorrentes ao "Prêmio Pesquisa Avícola José Maria Lamas da Silva"... Campinas : Facta,1998. p.55.

BACK, A. et al. Development of a serum plate agglutination test to detect antibodies to Ornithobacterium rhinotracheale. Journal of Veterinary Diagnostic Investigation, v.10, p.8486, 1998.

LEROY-SÉTRIN, S. et al. Genetic diversity of Ornithobacterium rhinotracheale strains isolated from poultry in France. Letters in Applied Microbiology, v.26, p.189$193,1998$.

SAMBROOK, R.; FRITSCH, E.F.; MANIATIS, T. Molecular cloning: a laboratory manual. 2.ed. Cold Spring Harbour : Cold Spring Harbour Laboratory, 1989. 3v.

VANDAMME P. et al. Ornithobacterium rhinotracheale gen. nov., sp. nov., isolated from the avian respiratory tract. International Journal Systematic Bacteriology, v.44, n.1, p.24-37, 1994.

VAN EMPEL, P.C.M. et al. Identification and serotyping of Ornithobacterium rhinotracheale. Journal of Clinical Microbiology, v.35, p.418-421, 1997.

VAN EMPEL, P.C.M.; VAN DEN BOSCH, H. Vaccination of chickens against Ornithobacterium rhinotracheale infection. Avian Diseases, v.42, p.572-578, 1998.

VAN EMPEL, P.C.M.; HAFEZ, H.M. Ornithobacterium rhinotracheale: a review. Avian Patology, v. 28, n.3, p.217227, 1999. 